\title{
US GEOLOGICAL SURVEY, WATER RESOURCES DIVISION, RADIOCARBON MEASUREMENTS I
}

\author{
F J PEARSON, JR and MARTHA BODDEN \\ US Geological Survey, Isotope Hydrology Laboratory \\ National Center, Reston, Virginia 22092
}

The Water Resources Division of the US Geological Survey has operated a low-level tritium laboratory since the late 1950's. In 1970, ${ }^{14} \mathrm{C}$-measuring facilities were added to that laboratory to provide analyses of ground water and other carbonates, primarily for research and field projects of the Division.

${ }^{14} \mathrm{C}$ analyses are made by liquid scintillation counting of benzene synthesized from sample carbonate by the reactions:

$$
\mathrm{CO}_{3}=\stackrel{\mathrm{H}^{+}}{\longrightarrow} \mathrm{CO}_{2} \stackrel{\mathrm{Li}}{\longrightarrow} \mathrm{Li}_{2} \mathrm{C}_{2} \stackrel{\mathrm{H}_{2} \mathrm{O}}{\longrightarrow} \mathrm{C}_{2} \mathrm{H}_{2} \stackrel{\text { catalyst }}{\longrightarrow} \mathrm{C}_{6} \mathrm{H}_{6}
$$

The $\mathrm{C}_{2} \mathrm{H}_{2}$ is produced by the method of Guntz $(1896,1898)$, more recently described by Barker (1953) and Hubbs and Bien (1967). To make $\mathrm{Li}_{2} \mathrm{C}_{2}$, we use about twice the stoichiometric amount of $\mathrm{Li}$ and add $\mathrm{CO}_{2}$ at pressures of $<15 \mathrm{~cm} \mathrm{Hg}$ to keep the temperature of the reaction relatively low (dull red heat). After $\mathrm{CO}_{2}$ is added, the mixture is held at the same temperature while open to a vacuum for ca $1 \mathrm{hr}$. With samples of normal size, ca $3 \mathrm{ml} \mathrm{C}_{6} \mathrm{H}_{6}, \mathrm{C}_{2} \mathrm{H}_{2}$ yields are consistently above $90 \%$. The $\mathrm{C}_{2} \mathrm{H}_{2}$ is purified and dried by passing it over $\mathrm{NaOH}$ pellets and glass beads coated with $85 \% \mathrm{H}_{3} \mathrm{PO}_{4}$. It is then catalytically polymerized to $\mathrm{C}_{6} \mathrm{H}_{6}$. The catalyst used is a commercial petroleum cracking catalyst, requiring only drying before use. The polymerization yields generally exceed $85 \%$ and the $\mathrm{C}_{6} \mathrm{H}_{6}$ is free of impurities that might cause quenching (Fraser et al, 1974). The method has been described in detail by Noakes, Kim, and Stipp (1966) and, more recently, by Fontes (1971).

The $\mathrm{C}_{6} \mathrm{H}_{6}$ is counted on a Picker Nuclear Liquemat 220* liquid scintillation counter with photomultiplier tubes selected for optimum ${ }^{14} \mathrm{C}$ sensitivity. The absence of quenching is vertified for each sample by the external standard channels ratio method. Samples through WRD-156 were counted in low-potassium glass vials, which held 4ml, $3 \mathrm{ml}$ sample benzene and $1 \mathrm{ml}$ toluene + scintillator. This arrangement had a background of ca $4.0 \mathrm{cpm}$ and a net modern count, $0.95 \mathrm{x}$ NBS oxalic acid, $3 \mathrm{ml} \mathrm{C}_{6} \mathrm{H}_{6}$, of ca $21 \mathrm{cpm}$. Samples following WRD-156 were counted in a $4 \mathrm{ml}$ capacity Teflon vial, identical to design " $\mathrm{A}$ " of Calf and Polach (1974). This vial, with $3 \mathrm{ml}$ sample benzene and $1 \mathrm{ml}$ toluene + scintillator, had a background count of ca $4.0 \mathrm{cpm}$ and a net modern count of 24cpm.

* Products are named for identification only and do not imply endorsement by US Geological Survey. 
Results are based on a modern of $0.95 \times$ NBS oxalic acid, and ${ }^{14} \mathrm{C}$ half-life of 5568 years. Errors are based on counting statistics and are $\pm 1 \sigma$, except for those samples whose counts approach either modern or background for which $2 \sigma$ limits are reported. Ground-water analyses are described at the beginning of that section.

Unless otherwise identified, collectors and submitters are USGS, WRD, personnel from the office specified.

\section{ACKNOWLEDGMENTS}

We are grateful to Meyer Rubin and Sam Valastro for providing check samples and other assistance in establishing this laboratory, and to $\mathrm{T} A \mathrm{~W}$ yerman for his invaluable assistance in optimizing the counting procedure. ${ }^{13} \mathrm{C}$ analyses were made by $\mathrm{C} \mathrm{T}$ Rightmire.

\section{SAMPLE DESCRIPTIONS}

I. CHECK SAMPLES

\begin{tabular}{lclcl}
\hline Sample no. & Age (yr) & $\begin{array}{l}\text { Other } \\
\text { lab no. }\end{array}$ & Age (yr) & Reference \\
\hline WRD-27 & $2330 \pm 100$ & W-2051 & $2200 \pm 250$ & $\begin{array}{c}\text { M Rubin, 1971, } \\
\text { pers commun }\end{array}$ \\
WRD-28 & $8950 \pm 150$ & W-568 & $9000 \pm 400$ & R, 1960, v 2, p 165 \\
WRD-29 & $31,000 \pm 2350$ & W-2043 & $28,000 \pm 1000$ & R, 1970, v 12, p 319 \\
WRD-63 & $3960 \pm 100$ & Tx-966 & $4050 \pm 80$ & R, 1972, v 14, p 467 \\
\hline
\end{tabular}

See also WRD-1, Washington series, and WRD-197-200, -203, -205, Southern Great Basin, Nevada and California series.

\section{GROUND-WATER SAMPLES}

Ground-water carbonate for ${ }^{14} \mathrm{C}$ analysis is collected in the field by direct precipitation of $\mathrm{SrCO}_{3}$ from $100 \mathrm{~L}$ of sample. The procedure is similar to that used by the IAEA (B Payne, 1970, written commun). In the laboratory, the wet precipitate is poured into a flask and $\mathrm{CO}_{2}$ evolved with acid. Samples containing a large amount of sulfide precipitated with the carbonate are oxidized with $\mathrm{H}_{2} \mathrm{O}_{2}$ to prevent $\mathrm{H}_{2} \mathrm{~S}$ formation when acid is added.

Separate samples for determination of $\delta^{13} \mathrm{C}$ of dissolved carbonate are obtained by adding an $\mathrm{NH}_{4} \mathrm{OH} \cdot \mathrm{SrCl}_{2}$ solution to $1 \mathrm{~L}$ of sample in the field (Gleason, Friedman, \& Hanshaw, 1969). $\delta^{13} \mathrm{C}$ values, reported below relative to $\mathrm{PDB}$, are for these samples.

Tritium analyses are made on most samples collected for ${ }^{14} \mathrm{C}$. Results are used to determine whether any admixture of recent water from faulty well construction, sampling technique, or natural water flow paths is likely to have effected the ${ }^{14} \mathrm{C}$ content of the water.

For ${ }^{14} \mathrm{C}$ samples, field measurements of alkalinity and $\mathrm{pH}$ are made, and laboratory analyses of 10 or more common dissolved constituents are made. From these data, distribution of dissolved species and degree 
of saturation of water related to several minerals are calculated using the computer program WATEQ (Truesdell and Jones, 1973). Values of total dissolved carbonate content,

$$
\left(\mathrm{C}_{\text {total }}=\mathrm{H}_{2} \mathrm{CO}_{3}+\mathrm{HCO}_{\overline{3}}^{-}+\mathrm{CO}_{\overline{3}}^{\overline{3}}+\mathrm{CaHCO}_{\overline{3}}^{-}+\mathrm{MgHCO}_{\overline{3}}^{-}+\text {etc }\right),
$$

reported below are from this program.

It is well known that the measured ${ }^{14} \mathrm{C}$ content of a ground-water carbonate depends on more than just the age of the water. Various schemes have been proposed to adjust measured ${ }^{14} \mathrm{C}$ values to calculate ages, eg, papers from IAEA $(1967,1970,1974)$. Our experience has been that no one scheme is universally satisfactory. Instead, we examine each series, using geochemical, stable isotope, conventional hydrologic, and any other available data to discern extent of processes, other than radioactive decay, which affect measured ${ }^{14} \mathrm{C}$ content. In some series, no ages are given because no unambiguous geochemical interpretation of the system could be made or because the wells sampled produced mixtures of waters from within the hydrologic system. Where ages are reported, comments describe ${ }^{1 \pm} \mathrm{C}$ adjustment procedure and geochemical information used.

\section{A. United States}

\section{South-Central Washington series}

Samples were part of study of characteristics of regional groundwater flow in an 11,600sq $\mathrm{km}$ area including the Pasco Basin and surrounding areas, S-central Washington. All wells draw water from basalt of Columbia River Group or from interbed zones in basalt sequence. The well numbers give Township/Range-Section-sequential letter and number. Samples coll and subm by A M LaSala, Jr and G C Doty, Richland, Washington. Comment: ${ }^{14} \mathrm{C}$ data are accordant with regional flow pattern suggested by hydrologic information (LaSala, Doty \& Pearson, 1973). General range of values similar to those reported from Pullman-Moscow Basin, Washington (Crosby \& Chatters, 1965). Errors reported to submitter incorrectly and pub (LaSala, Doty \& Pearson, 1973).

\section{Fresno and Kings Co, San Joaquin Valley, California series}

Extensive use of ground water for irrigation in the San Joaquin Valley has led to many studies of the ground-water hydrology of the region. A tritium study (Haskell, Leventhal, \& Bianchi, 1966), based on 1963 sampling of wells along 2 traverses on W side, suggested flow rates much greater than those estimated by conventional hydrologic methods (Poland, 1973). Consequently, in 1966-1968, and 1970, the USGS sampled and tested tritium content of well waters along the same 2 traverses to resolve the contradiction. The 1970 sampling was expanded to include wells 8 to $13 \mathrm{~km} \mathrm{SE}$, analyzed for both $\mathrm{T}$ and ${ }^{14} \mathrm{C}$ (results listed below). Well numbers give Township/Range-Sectionsequential letter and and number. Coll Aug 1970 by Raoul LeBlanc; subm by J F Poland, Sacramento, California. 


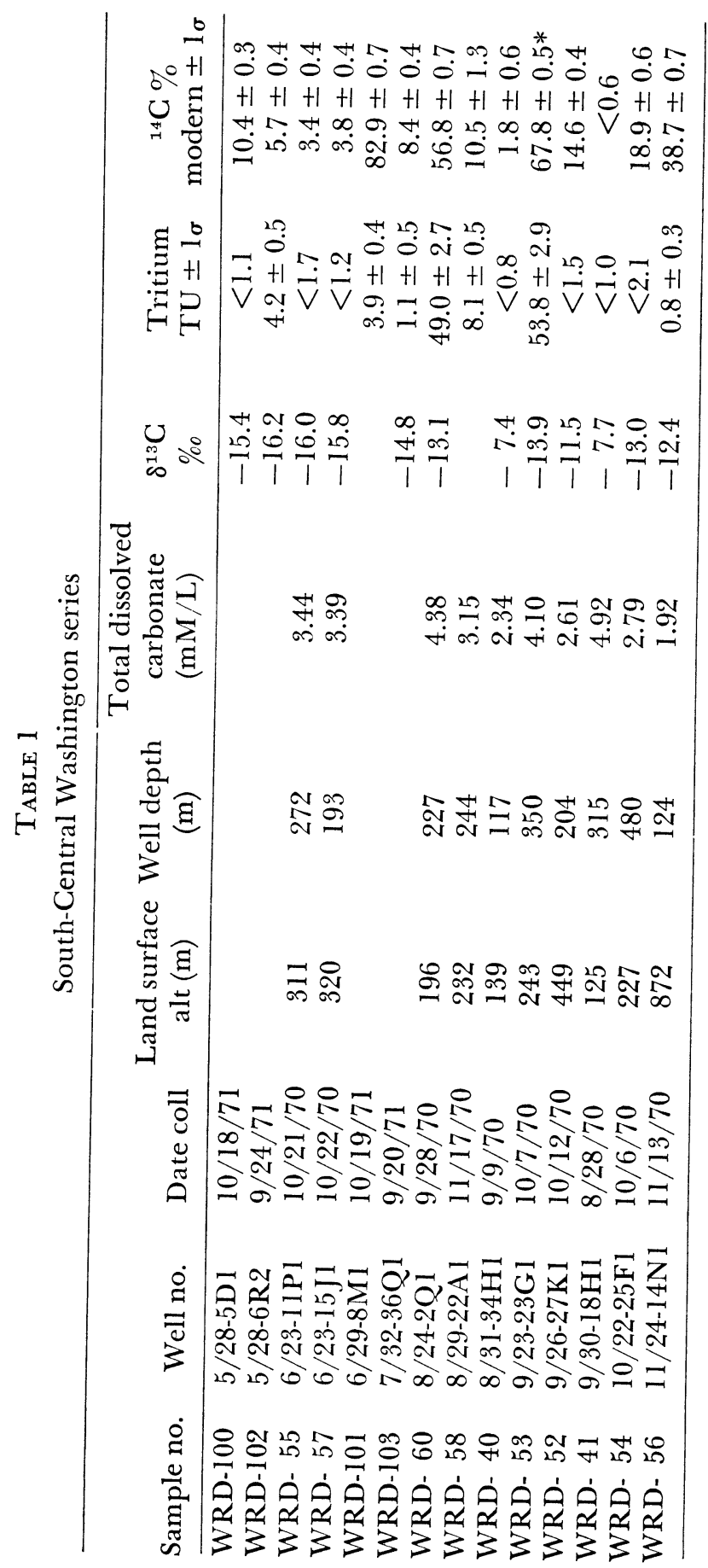




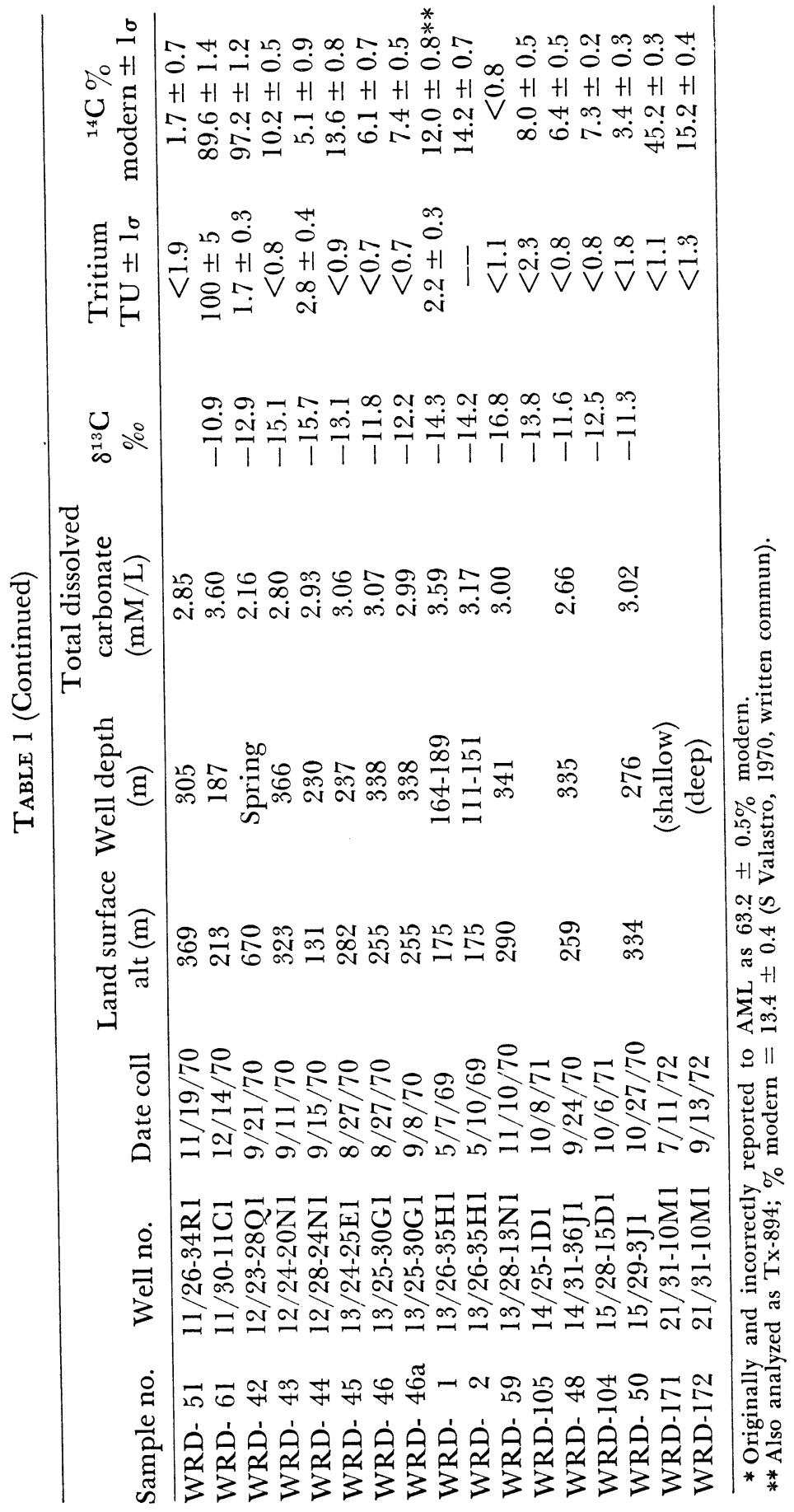




\begin{tabular}{lcccc}
\hline Sample no. & Well no. & $\begin{array}{c}\text { Tritium } \\
\text { TU } \pm 1 \boldsymbol{\sigma}\end{array}$ & $\delta^{13} \mathrm{C} \%$ \% & $\begin{array}{c}{ }^{14} \mathrm{C} \% \\
\text { modern } \pm 1 \boldsymbol{\sigma}\end{array}$ \\
\hline WRD-87 & 17S/20E-31F1 & $1.0 \pm 0.4$ & - & $14.8 \pm 0.9$ \\
WRD-88 & 18S/17E-13N2 & $<0.8$ & -22.9 & $3.2 \pm 0.4$ \\
WRD-97 & $18 \mathrm{~S} / 19 \mathrm{E}-31 \mathrm{G} 2$ & $<0.7$ & -4.8 & $1.0 \pm 0.2$ \\
WRD-98 & 18S/17E-31Q1 & - & -28.2 & $1.2 \pm 0.4$ \\
WRD-99 & 19S/18E-10N1 & $<0.7$ & -8.2 & $2.6 \pm 0.1$ \\
\hline
\end{tabular}

Comment (FJP): wells normally produce water from several horizons and adjusted ages of resulting mixture cannot be made. Generally low $T$ and ${ }^{14} \mathrm{C}$ contents suggest rapid flow rate estimated from previous $\mathrm{T}$ work is incorrect (Poland, 1973).

\section{Southern Great Basin, Nevada and California series}

Samples are from 4 groups of moderately hot $\left(25^{\circ}\right.$ to $\left.39^{\circ} \mathrm{C}\right)$ springs discharging, at valley level, from a regional carbonate rock aquifer system from an area $>11,600 \mathrm{~km}$. Samples were coll May and June 1973 to evaluate utility of environmental isotopes for definition of a hydrogeologically complex ground-water flow system. The hydrogeology and hydrochemistry of the region were described by Winograd $(1971) ; \delta^{13} \mathrm{C}$ and ${ }^{14} \mathrm{C}$ analyses are in progress. Tritium content of all sources was $<1$ TU. Coll and subm by I J Winograd, Reston, Virginia.

Comment (IJW): agreement in ${ }^{14} \mathrm{C}$ content between spring pairs in Pahranagat Valley, Death Valley, and Muddy $R$ areas was expected due to mean identity of water chemistry. The wide divergence (1.8 to $11.6 \%$ modern) of the 3 springs at Ash Meadows was a surprise, in view of similar water chemistry and ${ }^{13} \mathrm{C}$ content. Differences may reflect mixing of water from 2 sources or extreme hydrodynamic dispersion in a heterogeneous fractured aquifer.

Two orifices exist at Fairbanks Spring. WRD-197 was of SW orifice, as was DE-670293 (R, 1973, v 15, p 470); DE-670294 was of NE orifice. Grove et al (1969) do not describe which orifice they sampled.

\section{Arkansas Hot Springs series}

Following are from hot and cold wells and springs in vicinity of Hot Springs, Arkansas, which are part of the hydrologic system including the Arkansas Hot Springs. Sampling was part of geochemical and hydrologic study for management of Hot Springs National Park. Pearson, Bedinger, and Jones (1972) described preliminary results (WRD-146-156), and a final report on the work, including all basic data, is made by Bedinger et al (1973). Coll and subm Feb 1972 (WRD-146-156) and Sept 1972 (WRD-164-170) by M S Bedinger, Little Rock, Arkansas, and F J P. Comment: carbonate geochemistry of this system is as straightforward as any we have encountered. Adjustment of measured ${ }^{14} \mathrm{C}$ values by 


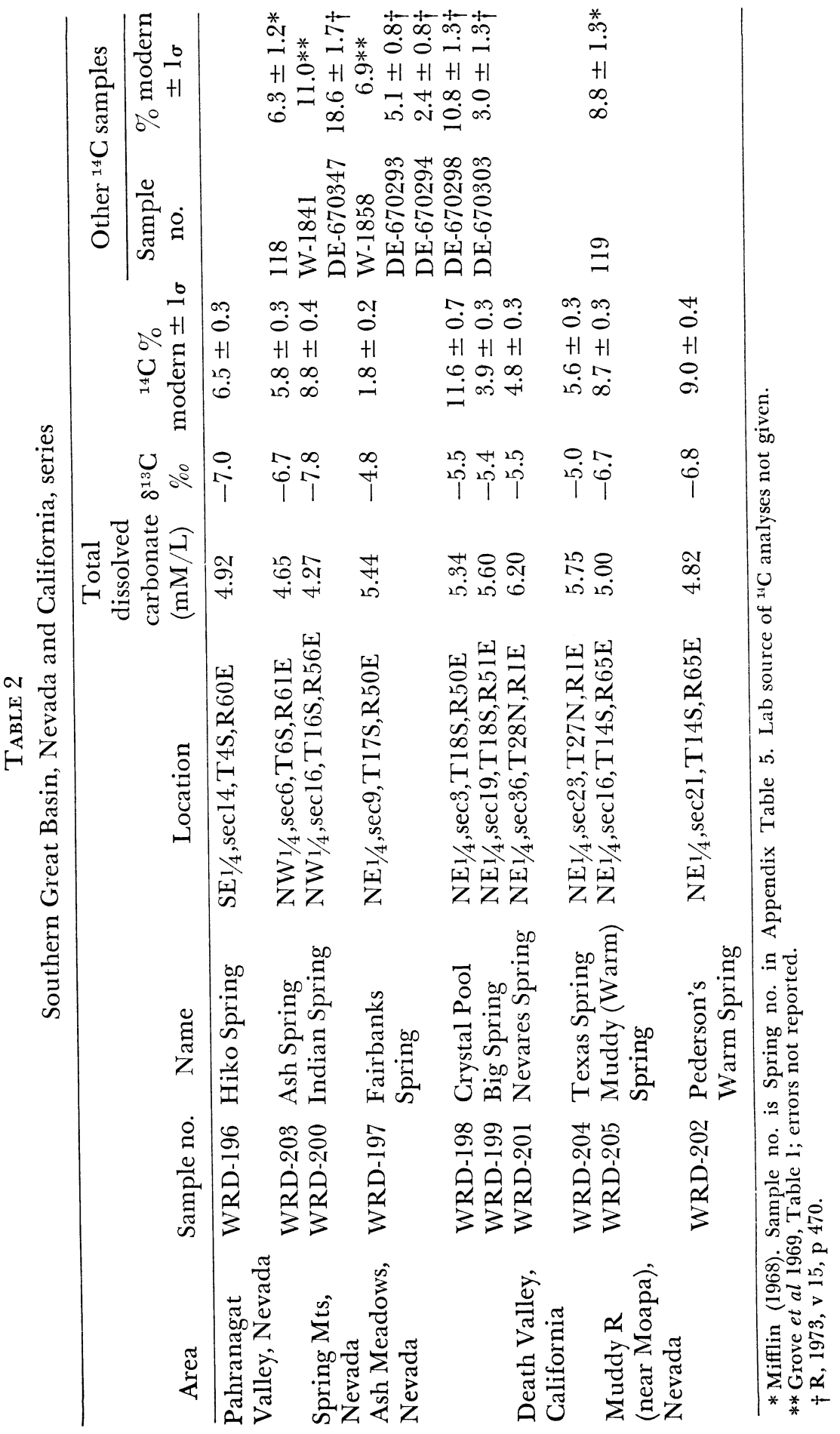




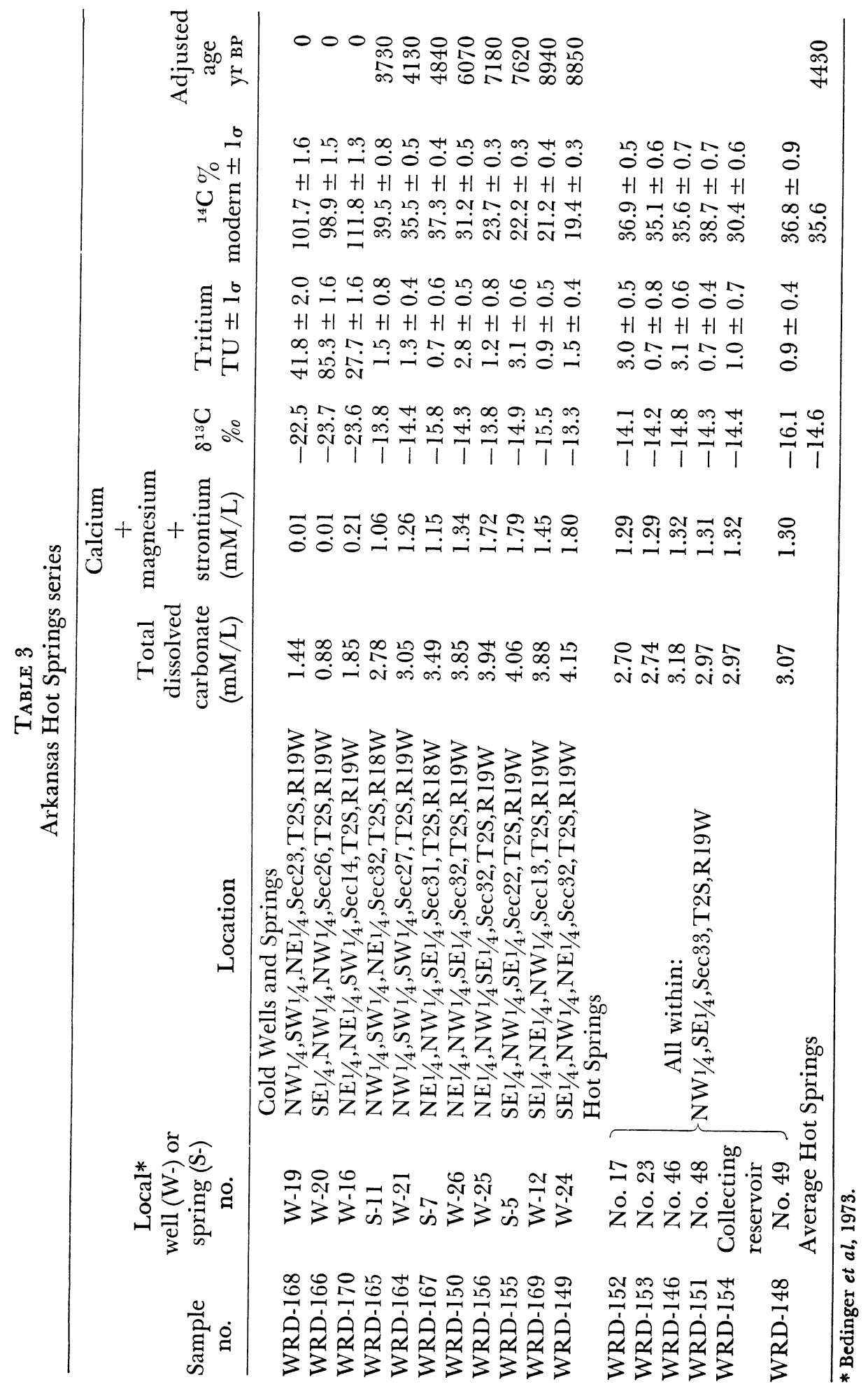


almost any conventional method using $\delta^{13} \mathrm{C}$ or water chemistry (Ingerson and Pearson, 1964; Pearson and Hanshaw, 1970; Tamers, 1967; Wendt et al, 1967) gives essentially the same results. In preliminary report (Pearson, Bedinger, and Jones, 1972), all ages adjusted using:

$$
{ }^{14} \mathrm{C}_{\mathrm{idj}}={ }^{14} \mathrm{C}_{\text {meas }} \times \frac{-23}{\delta^{13} \mathrm{C}_{\text {meas }}} .
$$

Here and in the final report (Bedinger et al, 1973), cold wells and springs were adjusted using:

$$
{ }^{14} \mathrm{C}_{\mathrm{adj}}={ }^{14} \mathrm{C}_{\text {meas }} \div 1-\left(\frac{\mathrm{C}_{\text {alkaline earth }}}{\mathrm{C}_{\text {total }}}\right) .
$$

Variable $\mathrm{CO}_{2}$ outgassing among Hot Springs gives unreliable $\mathrm{C}_{\text {total }}$ values, so adjustment was made only for average of hot springs using:

$$
{ }^{14} \mathrm{C}_{\mathrm{adj}}={ }^{14} \mathrm{C}_{\text {meas }} \times \frac{-24}{\delta^{13} \mathrm{C}_{\text {sample }}} .
$$

Adjusted ages and other geochemical data provide tests of assumptions made in digital models of water and heat flow in the Hot Springs system. Results show that the age of Hot Springs water is due largely to residence time in cold-water portion of the flow system rather than to an extended period in the zone of heating.

\section{Edwards Aquifer, Texas, series}

Following are from wells in the Edwards and assoc limestones aquifer in the San Antonio area, Texas (Garza, 1966; Petitt and George, 1956). The part of the Edwards studied is on the down-thrown, coastal side of the Balcones fault zone, near which, the Edwards supplies huge amounts of oxidizing $\mathrm{Ca}-\mathrm{HCO}_{3}$ water for irrigation and municipal supply, including that of the City of San Antonio. It discharges in springs used for recreation NE of San Antonio. Down dip (toward coast) there is a zone of rapid transition to water of a $\mathrm{Ca}-\mathrm{SO}_{4}$ to $\mathrm{Na}-\mathrm{Cl}$ type, reducing enough to contain $\mathrm{H}_{2} \mathrm{~S}$. These results are 1st of a series coll as part of comprehensive study of hydrology of the Edwards. Well numbers are those used by Texas Water Development Board (Rettman, 1969). Samples WRD-71-86 coll July, 1970 and WRD-110-129 coll July, 1971 by F J P, M B, and Paul Rettman. Subm by F J P. Comment: initial results agree with previous hydrologic concept of rapid water movement through oxidized part and relatively much slower movement in reducing part of aquifer. Detailed interpretation must await further geochemical work.

\section{Southeast Florida series}

Following results are from study of the use of deep saline aquifers for injection of liquid wastes and constitute a vertical section of hydrogeologic framework in SE Florida, near Miami. Study is to determine sources and relative ages of native fluids, degree of vertical hydraulic 
interconnection or separation, and whether saline water is residual from past sea-water intrusions or from recent influx of "moden" sea-water from adjacent Straits of Florida as part of an active ground-water circulation system.

Preston sample coll April 1972 by F W Meyer; Kendale samples coll July 1971 through March 1972 during drilling by D J McKenzie. Subm by M I Kaufman.

\begin{tabular}{lllr}
\hline Sample no. & Name & Lat, Long, aquifer, \& depth & $\begin{array}{c}{ }^{14} \mathrm{C} \% \\
\text { modern } \pm 1 \sigma\end{array}$ \\
\hline WRD-159 & $\begin{array}{l}\text { Preston Well } \\
\text { Field, S1476 }\end{array}$ & $\begin{array}{l}25^{\circ} 49^{\prime} 46^{\prime \prime} \mathrm{N}, 80^{\circ} 17^{\prime} 15^{\prime \prime} \mathrm{W} \\
\text { Biscayne Aquifer }\end{array}$ & $97.5 \pm 0.5$ \\
& Depth $32.6 \mathrm{~m}$ & \\
& Kendale Lakes & $25^{\circ} 41^{\prime} 24^{\prime \prime} \mathrm{N}, 80^{\circ} 24^{\prime} 53^{\prime \prime} \mathrm{W}$ & \\
WRD-162 & Test Well & Floridan Aquifer & \\
WRD-157 & & Depth 393.2m & $5.6 \pm 0.7$ \\
\hline
\end{tabular}

Comment (MIK): results indicate effective vertical hydraulic separation between Biscayne aquifer (modern) and upper Floridan aquifer $(\cong 5 \%$ modern). Although not definitive, age of upper Floridan waters and the extremely small amounts of ${ }^{14} \mathrm{C}$ from greater depths suggest a residual rather than a recent origin. Additional ${ }^{14} \mathrm{C}$ data is planned from future wells.

\section{Northwest Florida series}

WRD-160. Pensacola South Monitor Well $\left.14^{\prime} 17^{\prime \prime} \mathrm{W}\right)$. Part of study of use of deep saline aquifers for injection of liquid wastes. Represents native aquifer water from injection horizon $2.4 \mathrm{~km} \mathrm{~S}$ of industrial waste injection system in NW Florida, near Pensacola. Fresh water occurs within this aquifer ca $32.2 \mathrm{~km}$ upgradient. Dated to determine relative age of aquifer water. Coll Nov 1971 by L Slack and M I Kaufman. Subm by Kaufman. Comment (MIK): results suggestive of lethargic flow system and relatively old waters near injection site. Additional ${ }^{14} \mathrm{C}$ data is planned for overlying and upgradient waters to evaluate hydraulic separation and rates of ground-water movement. 
TABLE 4

Edwards Aquifer, Texas, series

\begin{tabular}{|c|c|c|c|c|c|}
\hline Sample no. & Well no. & $\begin{array}{c}\text { Total } \\
\text { dissolved } \\
\text { carbonate } \\
(\mathrm{mM} / \mathrm{L})\end{array}$ & $\begin{array}{c}\delta^{13} \mathrm{C} \\
\% o\end{array}$ & $\begin{array}{l}\text { Tritium } \\
\text { TU } \pm 1_{\sigma}\end{array}$ & $\begin{array}{c}{ }^{14} \mathrm{C} \% \\
\text { modern } \pm 1 \sigma\end{array}$ \\
\hline WRD-111 & $8-1900 *$ & 3.76 & -4.9 & $30.5 \pm 2.2$ & $116.0 \pm 1.1$ \\
\hline WRD-110 & $8-1950 *$ & 3.48 & -9.3 & $28.3 \pm 1.6$ & $118.0 \pm 1.1$ \\
\hline WRD-119 & YP-69-50-101 & 4.90 & -11.5 & $21.0 \pm 1.5$ & $72.5 \pm 0.6$ \\
\hline WRD-115 & YP-69-45-401 & 4.66 & -8.5 & $11.7 \pm 0.8$ & $65.6 \pm 0.7$ \\
\hline WRD-114 & TD-69-47-302 & 4.62 & -8.4 & $2.4 \pm 0.3$ & $62.4 \pm 0.6$ \\
\hline WRD-117 & TD-68-42-806 & 4.05 & -5.7 & $<0.8$ & $24.5 \pm 0.6$ \\
\hline WRD-118 & AY-68-35-904 & 4.49 & -8.5 & $1.9 \pm 0.7$ & $59.9 \pm 1.0$ \\
\hline WRD-112 & AY-68-36-102 & 5.36 & -8.9 & $13.9 \pm 0.8$ & $73.6 \pm 0.6$ \\
\hline WRD-116 & DX-68-23-301 & 5.30 & -9.2 & $6.7 \pm 0.4$ & $65.1 \pm 0.6$ \\
\hline WRD- 72 & AY-68-29-109 & 6.98 & -10.8 & $5.4 \pm 0.4$ & $73.8 \pm 0.7$ \\
\hline WRD- 75 & AY-68-37-104 & 4.83 & -8.6 & $4.4 \pm 0.3 * *$ & $83.6 \pm 1.1$ \\
\hline WRD- 85 & TD-69-40-901 & 4.95 & -9.6 & $11.5 \pm 1.2$ & $52.2 \pm 0.7$ \\
\hline WRD- 86 & AY-68-37-701 & 4.50 & -8.1 & $<0.7$ & $55.6 \pm 0.7$ \\
\hline WRD- 77 & TD-68-41-801 & 4.60 & -6.2 & $<0.8^{* *}$ & $5.8 \pm 0.4$ \\
\hline WRD-122 & AY-68-43-809 & 4.44 & -5.3 & - & $34.2 \pm 0.6$ \\
\hline WRD-125 & AY-68-43-703 & 4.42 & - & - & $22.8 \pm 0.6$ \\
\hline WRD-124 & AY-68-44-210 & 4.46 & -5.4 & $<1.0$ & $32.0 \pm 0.4$ \\
\hline WRD-121 & AY-68-38-101 & 4.10 & -4.3 & - & $21.0 \pm 0.6$ \\
\hline WRD-123 & KX-68-30-601 & 5.14 & -3.3 & $<1.8$ & $<1.4$ \\
\hline WRD- 84 & AY-68-45-802 & 5.44 & -3.2 & - & $<1.0$ \\
\hline WRD-129 & AY-68-45-802 & 4.81 & -6.9 & 一 & $<1.1$ \\
\hline WRD-128 & AY-68-45-101 & 5.20 & -3.1 & - & $<2.2$ \\
\hline WRD-127 & AY-68-38-301 & 6.55 & -4.0 & - & $<1.2$ \\
\hline WRD- 78 & AL-68-50-201 & 4.44 & -2.9 & - & $2.7 \pm 0.4$ \\
\hline WRD- 80 & AY-68-43-702 & 4.87 & -4.7 & - & $22.3 \pm 0.6$ \\
\hline WRD- 82 & AY-68-37-702 & 7.18 & 0.0 & $<0.6$ & $3.9 \pm 0.6$ \\
\hline WRD- 71 & AY-68-45-301 & 5.13 & -4.6 & - & $<2.4$ \\
\hline
\end{tabular}

* Stream samples.

** Coll in spring, 1968.

\section{Punjab series}

\section{B. Pakistan}

Samples are part of study to determine if salty ground water in irrigated doabs of upper Indus Plains, Punjab, Pakistan, is residual from conditions existing prior to irrigation or is currently being formed by evaporation of irrigation water. For details of study, see Seaber et al (1974).

Coll Feb and March 1971 by Ata and Gafar, WASID Lab, Govt Pakistan, and W Back, R Cherry, and P Seaber. Subm by C T Rightmire, Reston, Virginia. 


\begin{tabular}{|c|c|c|c|c|c|c|}
\hline Sample no. & Name & Lat $(\mathrm{N})$ & Long (E) & $\begin{array}{l}\delta^{13} \mathrm{C} \\
\% c c\end{array}$ & $\begin{array}{c}\text { Alkalinit } \\
(\mathrm{mM} / \mathrm{L})\end{array}$ & $\begin{array}{l}y \quad{ }^{14} \mathrm{C} \% \\
\text { modern } \pm 1 \sigma\end{array}$ \\
\hline RD- 91 & Kura & $31^{\circ} 41^{\prime}$ & $72^{\circ} 58^{\prime}$ & -5.8 & 4.2 & $78.6 \pm 1.2$ \\
\hline RD- 92 & Thatta Khushi & $\Gamma^{\prime}$ & $1 / 2$ & -19.7 & .11 & 1.0 \\
\hline RD- 93 & $\begin{array}{l}\text { Shorkot Road } \\
\text { hand pump }\end{array}$ & $7^{\prime}$ & 72 & - & 69 & 1.1 \\
\hline & Kama & & & & & 0.9 \\
\hline RD-106 & Go & $31^{\circ} 10^{\prime}$ & 7 & -10.5 & 5 & 0.6 \\
\hline RD-107 & Lyallpur & $4^{\prime}$ & 73 & -6.6 & 11.61 & $82.5 \pm 0.7$ \\
\hline VRD-108 & Test well, ZW-357 & $31^{\circ} 38^{\prime}$ & $73^{\circ} 55^{\prime}$ & - & 6.17 & $69.2 \pm 0.7$ \\
\hline NRD-109 & Toba Tek Singh & $30^{\circ} 59^{\prime}$ & $72^{\circ} 29^{\prime}$ & -6.0 & 4.38 & $97.3 \pm 0.8$ \\
\hline
\end{tabular}

Comment (CTR): due to lack of vertical control and possible mixing within wells, results of these ${ }^{14} \mathrm{C}$ determinations cannot be interpreted within regional hydrologic framework.

\section{Kenya}

\section{North Eastern Province series}

A body of fresh ground water underlies drainageways of Ewaso Ngiro R and Lagh Dera for ca $200 \mathrm{~km} \mathrm{SE}$ and $\mathrm{E}$ of Habaswein and is a major natural resource of arid North Eastern Prov. Samples coll to elucidate recharge mechanisms and perhaps flow rate to help plan use of this fresh water. Samples coll May, 1973 by F J P and W V Swarzenski, and Simon Wanuki, Water Dept, Govt Kenya. Comment: higher measured ${ }^{14} \mathrm{C}$ values are assoc with fresher water body, but correlation is not strict between ${ }^{14} \mathrm{C}$ and salinity. Samples fall into several groups; members of each show a striking correspondence between measured ${ }^{14} \mathrm{C}$ contents and $\left(\mathrm{C}_{\mathrm{tot}}\right)^{-1}$ values. Our hypothesis to account for this correspondence is that each of the ${ }^{14} \mathrm{C}-\mathrm{C}_{\text {tot }}$ groups represents a single recharge event. The different ${ }^{14} \mathrm{C}$ contents within each group are due to additions of varying amounts of ${ }^{14} \mathrm{C}$ free carbonate-by aquifer carbonate solution or mixing with older water-to water from a single recharge event.

Because of lack of general knowledge about arid-region carbonate chemistry and samples to show chemical and isotopic variations with depth in the aquifer, we do not assign absolute ages to these waters. It is probable, though, that recharge events recurred at intervals of a few milennia. Details of study are given by Pearson and Swarzenski (1974). 
TABLE 5

North Eastern Province series

\begin{tabular}{|c|c|c|c|c|c|c|c|}
\hline Sample no. & $\begin{array}{l}\text { Well no. } \\
\text { C- }\end{array}$ & Lat & Long & $\begin{array}{l}\text { Chloride } \\
(\mathrm{mg} / \mathrm{L})\end{array}$ & $\begin{array}{l}\text { Total } \\
\text { dissolved } \\
\text { carbonate } \\
(\mathrm{mM} / \mathrm{L})\end{array}$ & $\begin{array}{c}\delta^{13} \mathrm{C} \\
\% 0\end{array}$ & $\begin{array}{c}{ }^{14} \mathrm{C} \% \\
\operatorname{modern} \pm 10\end{array}$ \\
\hline WRD-184 & 3788 & $0^{\circ} 26^{\prime} \mathrm{N}$ & $40^{\circ} 01^{\prime} \mathrm{E}$ & 40 & 7.1 & -12.6 & $38.4 \pm 0.5$ \\
\hline WRD-183 & 3715 & $0^{\circ} 30^{\prime} \mathrm{N}$ & $39^{\circ} 51^{\prime} \mathrm{E}$ & 64 & 7.2 & -13.8 & $39.4 \pm 0.5$ \\
\hline WRD-182 & 3727 & $0^{\circ} 38^{\prime} \mathrm{N}$ & $39^{\circ} 42^{\prime} \mathrm{E}$ & 50 & 8.2 & -11.6 & $37.9 \pm 0.5$ \\
\hline WRD-194 & 2685 & $0^{\circ} 21^{\prime} \mathrm{N}$ & $40^{\circ} 52^{\prime} \mathrm{E}$ & 142 & 6.0 & -12.7 & $748.4 \pm 0.5$ \\
\hline WRD-177 & 3655 & $1^{\circ} 02^{\prime} \mathrm{N}$ & $39^{\circ} 27^{\prime} \mathrm{E}$ & 100 & 9.8 & -10.6 & $58.2 \pm 0.6$ \\
\hline WRD-193 & 3831 & $0^{\circ} 02^{\prime} \mathrm{S}$ & $40^{\circ} 27^{\prime} \mathrm{E}$ & 82 & 9.5 & -11.5 & $12.8 \pm 0.3$ \\
\hline WRD-178 & 3218 & $1^{\circ} 02^{\prime} \mathrm{N}$ & $39^{\circ} 29^{\prime} \mathrm{E}$ & 67 & 10.9 & -11.1 & $57.6 \pm 0.5$ \\
\hline WRD-195 & 3821 & $0^{\circ} 14^{\prime} \mathrm{N}$ & $40^{\circ} 21^{\prime} \mathrm{E}$ & 256 & 7.4 & -13.4 & $42.1 \pm 0.5$ \\
\hline WRD-181 & 3792 & $0^{\circ} 46^{\prime} \mathrm{N}$ & $39^{\circ} 37^{\prime} \mathrm{E}$ & 140 & 10.2 & -10.5 & $64.1 \pm 1.4$ \\
\hline WRD-187 & 3685 & $0^{\circ} 51^{\prime} \mathrm{N}$ & $39^{\circ} 34^{\prime} \mathrm{E}$ & 109 & 10.0 & - & $87.7 \pm 0.7$ \\
\hline WRD-180 & 3753 & $0^{\circ} 52^{\prime} \mathrm{N}$ & $39^{\circ} 27^{\prime} \mathrm{E}$ & 130 & 12.8 & -9.8 & $52.4 \pm 0.5$ \\
\hline WRD-188 & 3751 & $0^{\circ} 28^{\prime} \mathrm{N}$ & $39^{\circ} 44^{\prime} \mathrm{E}$ & 278 & 9.9 & -11.4 & $18.6 \pm 0.3$ \\
\hline WRD-189 & 3752 & $0^{\circ} 39^{\prime} \mathrm{N}$ & $39^{\circ} 35^{\prime} \mathrm{E}$ & 182 & 13.0 & -9.6 & $21.0 \pm 0.3$ \\
\hline WRD-192 & 3726 & $0^{\circ} 37^{\prime} \mathrm{N}$ & $40^{\circ} 01^{\prime} \mathrm{E}$ & 150 & 18.2 & -11.9 & $35.0 \pm 0.4$ \\
\hline WRD-185 & 3893 & $1^{\circ} 28^{\prime} \mathrm{N}$ & $39^{\circ} 16^{\prime} \mathrm{E}$ & 576 & 8.5 & -9.5 & $2.8 \pm 0.1$ \\
\hline WRD-191 & 3769 & $0^{\circ} 55^{\prime} \mathrm{N}$ & $39^{\circ} 53^{\prime} \mathrm{E}$ & 816 & 11.1 & -10.5 & $13.3 \pm 0.4$ \\
\hline WRD-190 & 3804 & $0^{\circ} 42^{\prime} \mathrm{N}$ & $39^{\circ} 28^{\prime} \mathrm{E}$ & 2700 & 31.0 & -10.6 & $7.3 \pm 0.3$ \\
\hline WRD-179 & 3822 & $1^{\circ} 02^{\prime} \mathrm{N}$ & $39^{\circ} 06^{\prime} \mathrm{E}$ & 2240 & 55.2 & -8.0 & $6.7 \pm 0.2$ \\
\hline WRD-186 & 3830 & $1^{\circ} 12^{\prime} \mathrm{N}$ & $39^{\circ} 15^{\prime} \mathrm{E}$ & 2720 & 38.7 & -8.9 & $28.9 \pm 0.4$ \\
\hline WRD-176 & 3770 & $0^{\circ} 01^{\prime} \mathrm{S}$ & $40^{\circ} 00^{\prime} \mathrm{E}$ & 3650 & 22.4 & -9.4 & $4.4 \pm 0.3$ \\
\hline
\end{tabular}

\section{REFERENCES}

Barker, Harold, 1953, Radiocarbon dating: large-scale preparation of acetylene from organic material: Nature, v 172, p 631-632.

Bedinger, M S, Pearson, F J, Jr, Reed, J E, Sniegocki, R T, and Stone, C G, 1973, The waters of Hot Springs National Park-their origin, nature, and management: US Geol Survey open-file rept, $122 \mathrm{p}$.

Calf, G E and Polach, H A, 1974, Teflon vials for liquid scintillation counting of carbon-14 samples in: Internatl symposium on liquid scintillation counting Proc, Sydney, Australia, 1973.

Crosby, J W, III and Chatters, R M, 1965, Water dating techniques as applied to the Pullman-Moscow ground-water basin: Coll Eng, Washington State Univ, Pullman, Bull 296, 21 p.

Fontes, J-Ch, 1971, Un ensemble destine a la mesure de l'achvile du radiocarbone naturel par scintillation liquide: Rev geog phys et geol dynamique, v 13, p 67-86.

Fraser, I, Polach, H A, Temple, B B, and Gillespie, R, 1974, Purity of benzene synthesized for liquid scintillation C-14 dating, in: Stanley, P E and Scoggins, B A (eds), Liquid scintillation counting; recent advances, N Y Academic Press, in press.

Garza, Sergio, 1966, Ground-water resources of the San Antonio area, Texas, A progress report on studies, 1960-1964: Texas Water Devel Bd Rept 34, 31 p.

Gleason, J D, Friedman, Irving, and Hanshaw, B B, 1969, Extraction of dissolved carbonate species from natural water for carbon isotope analysis: U S Geol Survey Prof Paper 650-D, p D248-D250. 
Grove, D B, Rubin, Meyer, Hanshaw, B B, and Beetem, W A, 1969, Carbon-14 dates of ground water from a Paleozoic carbonate aquifer, south-central Nevada: $U$ S Geol Survey Prof Paper 650-C, p C215 218.

Guntz, A, 1896, Action du lithium sur le carbone et quelques composes carbone: Acad sci [Paris] Comptes rendus, v 123, p 1273-1275.

1898, Sur la chaleur de formation du carbone de lithium: Acad sci [Paris] Comptes rendus, v 126, p 1866-1868.

Haskell, E E, Jr, Leventhal, J S, Bianchi, W C, 1966, The use of tritium to measure the movement of groundwater toward irrigation wells in western Fresno County, California: Jour Geophys Research, v 71, p 3849-3859.

Hubbs, G L and Bien, G S, 1967, La Jolla natural radiocarbon measurements V: Radiocarbon, v 9, p 261-294.

IAEA, 1967, Isotopes in Hydrology: Internatl Atomic Energy Agency, Vienna, 740 p.

IAEA, 1970, Isotope Hydrology 1970: Internatl Atomic Energy Agency, Vienna, 918 p.

IAEA, 1974, in press.

Ingerson, Earl and Pearson, F J, Jr, 1964, Estimation of age and rate of motion of ground-water by the ${ }^{14} \mathrm{C}$ method in: Recent researches in the fields of atmosphere, hydrosphere, and nuclear geochemistry, Tokyo, Maruzen Co, p 263-283.

LaSala, A M, Jr, Doty, G C, and Pearson, F J, Jr, 1973, The regional ground water flow system of south central Washington: U S Geol Survey open-file rept, $55 \mathrm{p}$.

Mifflin, M D, 1968, Delineation of ground-water flow systems in Nevada: Desert Research Inst, Univ Nevada, Tech rept ser $\mathrm{H}-\mathrm{W}$, pub 4, $111 \mathrm{p}$.

Noakes, J E, Kim, S M, and Stipp, J J, 1966, Chemical and counting advances in liquid scintillation age dating in: 6th internatl conf, radiocarbon and tritium dating Proc, Pullman, Washington, June 7-11, 1965: USAEC rept CONF-650652, p 68-92.

Pearson, F J, Jr, Bedinger, M S, and Jones, B F, 1972, Carbon-14 ages of water from the Arkansas Hot Springs: 8th internatl radiocarbon dating conf Proc, Wellington, New Zealand, p D19-D30.

Pearson, F J and Hanshaw, B B, 1970, Sources of dissolved carbonate species in groundwater and their effects on Carbon-14 dating in: Isotope Hydrology, 1970, Vienna, IAEA, p 271-285.

Pearson, F J, Jr and Swarzenski, W V, 1974, Carbon-14 evidence for the origin of arid region ground water: North Eastern Province, Kenya in: Symposium on isotope techniques in groundwater hydrology Proc, March 1974, Vienna, IAEA, in press.

in press.
Petitt, B M, Jr and George, W O, 1956, Ground-water resources of the San Antonio area, Texas: Texas Board Water Eng Bull 5608, v 1, 80 p.

Poland, I F, 1973, New tritium data on movement of ground water in western Fresno County, California (abs): Am Geophys Union Trans, v 54, no. 11, p 1077.

Rettman, Paul, 1969, Records of wells and springs, San Antonio area, Texas: Edwards Underground Water Dist, San Antonio, 29 p.

Seaber, P R, Back, William, Rightmire, C T, and Cherry, R N, 1974, Genesis of hydrogeochemical facies of ground water in the Punjab region of Pakistan, in: Symposium on development of groundwater resources Proc, Madras, India, in press

Tamers, M A, 1967, Radiocarbon ages of groundwater in an arid zone unconfined aquifer, in: Isotope techniques in the hydrologic cycle, Geophys Mon no. 11, Washington, Am Geophys Union, p 143-152.

Truesdell, A H and Jones, B F, 1973, WATEQ-A computer program for calculating chemical equilibria in natural waters: Natl Tech Inf Service, TB-220464.

Wendt, I, Stahl, W, Geyh, M, and Fauth, F, 1967, Model experiment for ${ }^{14} \mathrm{C}$ waterage determinations, in: Isotopes in Hydrology, Vienna, IAEA, p 321-337.

Winograd, I J, 1971, Origin of major valley-level springs in Amargosa Desert, Nevada and Death Valley, California: unpub PhD dissert, Univ Arizona, $170 \mathrm{p}$. 